Research article

\title{
RELATIONSHIPS BETWEEN THOROUGHBREDS' CONTRIBUTION IN THE PEDIGREE AND THE LEVEL OF FEARFULNESS AND PERFORMANCE IN WARMBLOOD STALLIONS
}

\author{
BUDZYŃSKA Monika*, KAMIENIAK Jarosław, MARCINIAK Beata, \\ SOETYS Leszek
}

Department of Ethology and Animal Welfare, Faculty of Biology, Animal Science and Bioeconomy, University of Life Sciences in Lublin, Poland

(Received 11 May, Accepted 28 August 2018)

The aim of this study was to test the hypothesis that Thoroughbred (TB) ancestors blood percentage in a pedigree is a potential factor differentiating the level of fearfulness (based on behavior and heart rate (HR)) and performance scores in warmblood stallions. A total of 267 three-year-old warmblood stallions were subjected to the novel-object based test during their participation in the performance tests' program. The effect of ancestors percentage contribution in the pedigree was analyzed by taking into account horses of four TB $(<25.01,25.01-50.00,50.01-75.00,>75.00 \%)$ ancestor groups. It was found that the stallions with a higher proportion $(>75.00 \%)$ of TB blood revealed higher values of HR measured at the riding hall just before the start of the fearfulness test. The results showed that the higher proportions of TB ancestors blood in the stallions' pedigree were correlated with the higher values for total time to pass novel objects when led by a handler during the fearfulness test. Negative correlations were found between the TB percentage and the scores for character and trot evaluated by the trainer as well as rideability evaluated by the test rider. The findings imply that a high proportion of Thoroughbreds in the pedigree may negatively influence some performance traits and increase fear reactivity in warmblood stallions.

Key words: ancestor, fearfulness, horse, pedigree, performance, Thoroughbred

\section{INTRODUCTION}

Warmblood horses all over the world are used for riding, from leisure to the Olympic sports disciplines such as dressage, show jumping and eventing [1]. Physical and behavioral traits of riding horses are important not only to select an adequate individual for a particular sport discipline or a type of riding, but also to select an animal that is easy and safe to handle and use [2]. The performance evaluation at the training center is used as a tool of early selection of potentially the most suitable stallions

\footnotetext{
*Corresponding author: e-mail: monika.budzynska@up.lublin.pl
} 
for breeding and/or top sport competition. The selection of stallions for dressage, show jumping or other disciplines involves the evaluation of genetic parameters, as well as the estimation of performance traits according to the selection criteria [3]. The study of Wallin et al [4] on Swedish warmblood riding horses showed significant correlations between performance test scores and later results in dressage and show jumping competitions. However, when horses are primarily intended to be used as leisure horses, behavior-related traits such as character and temperament may have a higher weighting than sport performance [1]. Behavior-related traits play an important role in horses for several reasons [5]. The balanced temperament of a horse influences its quality as a riding partner, as well as simplifies daily work and makes handling more comfortable and safe [6,7]. A horse's fear reactivity is considered to be an important attribute for accident prevention [5]. The horse is a prey species that tends to react with predator avoidance to potential stressful stimuli $[8,9]$. However, the horses' ability to habituate to a range of frightening stimuli greatly increases safety of both animals and humans [8]. Fear-related responses include behavioral and physiological changes involved in animal's adaptive mechanisms to cope with threatening situations $[10,11]$. Because fear reactivity is thought to be determined by various factors (for e.g. genetic, sex, age, human-animal relation), scientists, veterinarians, and breeders are likely to be interested in implementing detailed temperament assessments to horse selection programs $[2,5,9,12]$.

Many riding horse breeds are composed using several breeds to improve the desired traits in the progeny [13-15]. The genetic contribution of ancestors breed such as Thoroughbreds varies in particular generations and magnitude. The amount of crossbreeding with Thoroughbreds which are typically used to increase horse nobility may be one of the most important factors for breed-specific conformation traits [16]. However, analysis of genetic influence on individual phenotype value can involve also linking horse ancestors contribution with the assessment of behavioral and physiological reactivity in the temperament test and particular performance test results. The aim of this study was to test the hypothesis that Thoroughbred (TB) ancestors blood percentage in a pedigree is a potential factor differentiating the level of fearfulness and performance in warmblood stallions.

\section{MATERIAL AND METHODS}

\section{Horses and their groups of several percentage of Thoroughbred ancestors blood}

A total of 267 three-year-old warmblood stallions were subjected to the fearfulness assessment during their participation in the performance tests program for riding horses in Poland. The blood percentage estimates how much an individual TB ancestor contributes to a horse's pedigree. Sire and dam each (generation 1) make up 50\% of the pedigree, grandsires and granddams (generation 2) $25 \%$, great-grandparents (generation 3) contribute $12.5 \%$, and each ancestor of generation 4 contributes $6.25 \%$, 
etc. Every time a nominated TB ancestor appears in the pedigree, the percentage values are added together and their blood percentage can be estimated. For example, a Thoroughbred ancestor that appears in the grandparent generation contributes $25 \%$, and if it also appears in the great-grandparent generation $(12.5 \%)$, as well as in the fourth generation $(6.25 \%)$, then it has a blood percentage of $37.5 \%(25+12.5+6.25)$. The pedigree data of stallions were analyzed using four generations $(\mathrm{g})$ of every horse's ancestors to estimate the percentage of TB blood in the studied stallions pedigrees. The sum of four potential percentages $(g 1+g 2+g 3+g 4)$ was considered as the total ancestors percentage of TB blood. The effect of ancestors' percentage contribution in the pedigree was analyzed by taking into account the horses of four Thoroughbred $(<25.01,25.01-50.00,50.01-75.00,>75.00 \%)$ ancestor groups.

\section{Ethics}

In this study non-invasive methods were used and they were approved by the ethics committee. The national law on care and use of animals was followed as well.

\section{Assessment of fearfulness level}

Behavioral and physiological reactivity of stallions was assessed with the novel-object based test ('fearfulness test' according to Budzyński [17]) at the end of the training period (before the final performance test). The fearfulness test was conducted at the training center riding hall. The horses were led by hand by a familiar handler. The fearfulness test consisted of three sessions: (I) testing the individual response to a moving visual stimulus (two rotating (40 rotations/min) black-white squares $(1 \mathrm{~m} \mathrm{x}$ $1 \mathrm{~m})$ ), (II) testing the individual response to an auditory stimulus (metronome sound of 80 tones/min, with a sound frequency of $440 \mathrm{~Hz}$ and a sound intensity of $90 \mathrm{~dB}$ ) and not moving visual stimulus (previously mentioned squares but not rotating), and (III) testing the response to a moving visual stimulus (previously mentioned rotating squares) and an auditory stimulus (previously mentioned metronome sound) [2]. The characteristics of the fearfulness test have been described previously $[2,17,18]$. Horse behavior reactivity during every session of the fearfulness test was assessed by a trained observer using a decreasing reactivity scale (1 to 10 points): a score ranking from 1 (very fearful, the novel objects were not passed at all) to 10 (very fearless, passing by the novel objects without hesitation) (Table 1).

Every stallion was scored twice at each of the three test sessions: p1 - first point scoring the response to the test stimuli, $\mathrm{p} 2$ - second point scoring the response to the test stimuli [2]. The first scoring was done when the horse was led next to the devices generating the stimuli (novel objects) hidden by the boards and after reversing by a handler, the second scoring was done when the horse again was led next to the novel objects, this time not hidden by the boards [2]. At each of the three test sessions the second scoring was done directly after the first one. As a total behavior score of each session: I, II and III (behavior score I, behavior score II, behavior III) the sum 
of two scorings (points $\mathrm{p} 1+\mathrm{p} 2$ ) was considered [2]. The maximum time allowed for each session was set to 60 seconds and was controlled with a stopwatch. A measure of the total time (in seconds) for leading a horse at each of the three test sessions: I, II and III (total time I, total time II, total time III), was recorded for every horse. Prior to the novel-object based test (the fearfulness test) the heart rate monitor and receiver (Polar 810i, OY ELECTRO, Finland) were attached to the horse still in its stall. For each stallion, HR was telemetrically recorded in $5 \mathrm{sec}$ intervals during the whole testing (fearfulness test). The HR values at the riding hall before novel-object based testing (HR before testing), in the first fearfulness test session (HR I), in the second fearfulness test session (HR II) and in the third fearfulness test session (HR III) were evaluated.

Table 1. Scale to assess horse's behavior during fearfulness test $[2,17,18]$

\begin{tabular}{lc}
\hline Behavior & Points \\
\hline $\begin{array}{l}\text { Very fearful horse, jumping and moving back, willing to escape, does not continue passing } \\
\text { by the novel objects despite a handler's encouragement }\end{array}$ & 1 \\
\hline $\begin{array}{l}\text { Horse is jumping or moving back, willing to escape, does not continue passing by the } \\
\text { novel objects despite a handler's encouragement }\end{array}$ & 2 \\
$\begin{array}{l}\text { Horse is jumping and moving back, continues passing by the novel objects after several } \\
\text { trials of a handler's encouragement }\end{array}$ & 3 \\
\hline $\begin{array}{l}\text { Horse is jumping or moving back, continues passing by the novel objects after several } \\
\text { trials of a handler's encouragement }\end{array}$ & 4 \\
$\begin{array}{l}\text { Horse is stopping and moving back, continues passing by the novel objects with hesitation } \\
\text { Horse is stopping or moving back, continues passing by the novel objects with hesitation }\end{array}$ & 5 \\
\hline $\begin{array}{l}\text { Horse is slowing and walking sideways, looking at the novel object, continues passing with } \\
\text { interest towards the novel objects }\end{array}$ & 7 \\
\hline $\begin{array}{l}\text { Horse is slowing or walking sideways, looking at the novel object, continues passing with } \\
\text { interest towards the novel objects }\end{array}$ & 8 \\
\hline $\begin{array}{l}\text { Horse is passing without hesitation and no change in pace, looking at the novel objects } \\
\text { Very fearless horse, passing without hesitation and no change in pace, no interest towards } \\
\text { the novel objects }\end{array}$ & 9 \\
\hline
\end{tabular}

\section{Performance test data}

The final performance test data of stallions included: the traits assessed by the trainer ( $T$; a chair of the training center) such as: trainability, character, temperament, free jumping, jumping under a rider, walk, trot and canter, the traits assessed by the PHBA (Polish Horse Breeders Association) judges (J): free jumping, jumping under a rider, walk, trot, canter and final index as well as the traits: rideability, rideability dressage and rideability jumping that were assessed by a test rider $(\mathrm{R})$. The performance traits were rated on a 10 -point scale, from $1=$ very bad to $10=$ excellent [2]. The final index was evaluated by a 1 to 5 rating scale (from insufficient to perfect) based on a total point 
number calculated for all estimated performance traits according to the detailed rules of 100-day stallions performance tests assessment given in Breeding Programs for Warmblood Horses by the PHBA [2,19].

\section{Statistical analysis}

The results of the study were presented as arithmetic means and standard deviations (SD). A Wilcoxon test was used to detect differences within groups, Mann-Whitney-U to test differences between groups, and Spearman correlations between TB ancestors' blood percentages in the pedigree and indicators of their fearfulness and performance were calculated (STATISTICA 10.0). In the present study, the differences between means and correlation coefficients were considered as statistically significant when $\mathrm{P} \leq 0.01$ or $\mathrm{P} \leq 0.05$.

\section{RESULTS}

The present results support the hypothesis on the relationships between Thoroughbred ancestors blood percentage and the level of some fearfulness indicators and performance test scores in warmblood stallions. The results of behavioral and physiological reactivity of the stallions assessed in the fearfulness test are shown in Table 2. An increased proportion $(>75.00 \%)$ of TB blood in the stallions pedigree significantly influences their heart rate measured at the riding hall before novel-object testing. Thus, it can be stated that TB ancestors contribution influences the level of physiological reactivity estimated by the HR level. However, there was no significant difference in behavior scores and total time values in the fearfulness test between stallions with several ranges of TB ancestors blood percentage. The behavior scores in the studied horses revealed significant differences among particular test sessions (I,II,III) at $\mathrm{P} \leq 0.01$ and $\mathrm{P} \leq 0.05$ in horses within groups of several percentage of $\mathrm{TB}$ contribution. The lowest behavior score was established in the stallions (regardless of TB ancestors blood percentage) taking the first test session and their reactivity was decreasing during the second and the third test session. The heart rate monitoring in the studied horses revealed significant differences among HR before novel-object testing and HR during particular test sessions (I,II,III) at P $\leq 0.01$ in horses within the group of $25.01-50 \%$ or $50.01-75 \%$ percentage of TB contribution (Table 2 ).

Mean values of performance traits of warmblood stallions assessed in performance tests are shown in Table 3. For the character scores we found a significant trend showing that stallions with a high proportion $(>75.00 \%)$ of TB blood were worse evaluated (at $\mathrm{P} \leq 0.05$ ) in comparison to the horses with less than $25.01 \%$ TB in their pedigree. Moreover, a higher proportion of TB blood negatively influenced the score for trot evaluated by both, the trainer and the judges. 
Table 2. Behavior scores (points), total time (s) and HR values (beats/min) in stallions assessed in the sessions I, II and III of fearfulness test in relation to several ranges of TB ancestor's blood percentage

\begin{tabular}{|c|c|c|c|c|c|c|c|c|}
\hline \multirow{3}{*}{$\begin{array}{l}\text { Fearfulness } \\
\text { indicators }\end{array}$} & \multicolumn{8}{|c|}{ several ranges of Thoroughbred ancestor's blood percentage } \\
\hline & \multicolumn{2}{|c|}{$\begin{array}{l}<25.01 \\
\mathrm{n}=21\end{array}$} & \multicolumn{2}{|c|}{$\begin{array}{c}25.01-50.00 \\
\mathrm{n}=135\end{array}$} & \multicolumn{2}{|c|}{$\begin{array}{c}50.01-75.00 \\
\mathrm{n}=91\end{array}$} & \multicolumn{2}{|c|}{$\begin{array}{l}>75.00 \\
\mathrm{n}=20\end{array}$} \\
\hline & Mean & SD & Mean & SD & Mean & SD & Mean & SD \\
\hline Behavior s & $4.71^{\mathrm{a}}$ & 4.96 & $14.73^{\mathrm{AB}}$ & 3.93 & $14.92^{\mathrm{AB}}$ & 4.28 & $15.05^{\mathrm{aB}}$ & 3.85 \\
\hline Behavior score II & $16.50^{\text {a }}$ & 2.78 & $16.30^{\mathrm{A}}$ & 2.89 & $16.47^{\mathrm{A}}$ & 3.28 & $16.05^{\text {ac }}$ & 4.01 \\
\hline Behavior score III & 16.00 & 3.48 & $16.34^{\mathrm{B}}$ & 3.22 & $16.34^{\mathrm{B}}$ & 3.56 & $16.42^{\mathrm{Bc}}$ & 4.19 \\
\hline Total time I & 7.66 & 4.39 & 23.31 & 19.11 & $24.95^{\mathrm{CD}}$ & 21.09 & 26.58 & 24.48 \\
\hline Total time II & 17.42 & 1.89 & 19.77 & 13.25 & $20.43^{\mathrm{C}}$ & 16.05 & 23.47 & 23.45 \\
\hline Total time III & 18.39 & 4.50 & 19.71 & 13.53 & $20.57^{\mathrm{D}}$ & 16.01 & 23.81 & 23.38 \\
\hline HR before testing & 63.94 & 34.89 & $54.83^{\mathrm{CDEX}}$ & 27.35 & $55.75^{\mathrm{EFGY}}$ & 26.96 & $78.95^{\mathrm{XY}}$ & 37.99 \\
\hline HR I & 89.47 & 33.08 & $93.61 \mathrm{CFG}$ & 36.96 & $96.42^{\mathrm{EHI}}$ & 33.81 & 92.16 & 32.43 \\
\hline HR II & 80.37 & 27.87 & $80.88^{\mathrm{DF}}$ & 25.17 & $86.04^{\mathrm{FH}}$ & 27.30 & 90.53 & 32.86 \\
\hline HR III & 83.06 & 33.96 & $85.69^{\mathrm{EG}}$ & 33.11 & $87.57^{\mathrm{GI}}$ & 33.04 & 91.32 & 34.35 \\
\hline
\end{tabular}

Means (in columns) denoted with the same letters: CAPITAL (A-G) differ significantly at $P \leq 0.01$ and small (a-c) at $\mathrm{P} \leq 0.05$. Means (in rows) denoted with the same letters $(\mathrm{X}, \mathrm{Y})$ differ significantly at $\mathrm{P} \leq 0.01$

Table 3. Performance tests scores in stallions in relation to several ranges of TB ancestor blood percentage

\begin{tabular}{|c|c|c|c|c|c|c|c|c|}
\hline \multirow{3}{*}{$\begin{array}{l}\text { Traits evaluated by } \\
\mathrm{T} \text { - trainer, } \\
\text { J - judges, } \\
\mathrm{R} \text { - test rider }\end{array}$} & \multicolumn{8}{|c|}{ several ranges of Thoroughbred ancestor's blood percentage } \\
\hline & \multicolumn{2}{|c|}{$\begin{array}{l}<25.01 \\
\mathrm{n}=21\end{array}$} & \multicolumn{2}{|c|}{$\begin{array}{c}25.01-50.00 \\
\mathrm{n}=135\end{array}$} & \multicolumn{2}{|c|}{$\begin{array}{c}50.01-75.00 \\
\mathrm{n}=91\end{array}$} & \multicolumn{2}{|c|}{$\begin{array}{l}>75.00 \\
\mathrm{n}=20\end{array}$} \\
\hline & Mean & SD & Mean & SD & Mean & SD & Mean & SD \\
\hline Trainability (T) & 6.97 & 0.79 & 6.93 & 0.93 & 6.75 & 0.92 & 6.68 & 0.75 \\
\hline Character $(\mathrm{T})$ & $8.33^{a}$ & 0.84 & 8.18 & 1.16 & 8.01 & 1.10 & $7.68^{\mathrm{a}}$ & 1.06 \\
\hline Temperament $(T)$ & 7.85 & 0.37 & 7.76 & 0.79 & 7.67 & 0.87 & 7.81 & 0.75 \\
\hline Free jumping $(\mathrm{T})$ & 6.92 & 0.83 & 7.03 & 0.98 & 7.02 & 0.85 & 7.00 & 0.55 \\
\hline Jumping under rider $(\mathrm{T})$ & 6.72 & 0.75 & 6.68 & 0.97 & 6.58 & 0.96 & 6.68 & 0.78 \\
\hline Walk (T) & 6.94 & 0.87 & 6.96 & 1.04 & 6.86 & 0.84 & 6.79 & 1.03 \\
\hline $\operatorname{Trot}(\mathrm{T})$ & $6.97^{a}$ & 0.81 & 6.81 & 0.96 & 6.72 & 0.79 & $6.29^{a}$ & 0.87 \\
\hline Canter $(\mathrm{T})$ & 7.22 & 0.86 & 7.16 & 0.92 & 7.08 & 0.76 & 7.05 & 0.91 \\
\hline Free jumping $(J)$ & 6.55 & 0.62 & 6.92 & 0.84 & 6.88 & 0.83 & 6.91 & 0.63 \\
\hline Jumping under rider (J) & 6.46 & 0.89 & 6.74 & 0.83 & 6.72 & 0.82 & 6.61 & 0.69 \\
\hline Walk (J) & 6.89 & 0.63 & 7.03 & 0.67 & 7.10 & 0.68 & 6.96 & 0.96 \\
\hline $\operatorname{Trot}(J)$ & 6.50 & 0.82 & $6.89^{a}$ & 0.79 & $6.75^{\mathrm{b}}$ & 0.77 & $6.56^{\mathrm{ab}}$ & 0.88 \\
\hline Canter $(J)$ & 6.71 & 0.69 & 7.05 & 0.62 & 7.01 & 0.74 & 6.87 & 0.89 \\
\hline Rideability (R) & 5.72 & 1.24 & 5.85 & 1.62 & 5.71 & 1.66 & 4.86 & 1.90 \\
\hline Rideability dressage (R) & 5.79 & 1.42 & 5.56 & 2.12 & 5.34 & 1.84 & 4.99 & 2.00 \\
\hline Rideability jumping (R) & 5.58 & 1.59 & 5.63 & 1.89 & 5.36 & 1.94 & 5.12 & 1.64 \\
\hline Final index $(J)$ & 3.17 & 1.15 & 3.51 & 0.92 & 3.44 & 0.95 & 3.10 & 0.87 \\
\hline
\end{tabular}

Means (in rows) denoted with the same letters (a, b) differ significantly at $\mathrm{P} \leq 0.05$

The results showed a low relationship between TB ancestors blood percentages and the indicators of fear reactivity (Table 4). The TB ancestors blood percentage was positively correlated with the total time values during session I in the fearfulness test. 
The higher the proportions of TB ancestors revealed in the pedigree, the higher values for total time to pass the novel objects when led by a handler during the fearfulness test were obtained. There were no significant relationships between the ancestors blood percentages and the behavior scores, as well as HR values in the fearfulness test. There were more significant relationships between TB ancestors blood percentages and performance traits in the studied stallions (Table 5). There were negative correlations between the TB ancestors blood percentage and the scores for character and trot evaluated by the trainer, as well as for rideability evaluated by the test rider. The higher proportion of ancestors blood was revealed in the pedigree, the lower scores for some performance traits the stallions received.

Table 4. Correlation coefficients between fearfulness assessment results and TB ancestor's blood percentage in stallions' pedigree

\begin{tabular}{lc}
\hline Fearfulness indicators & $\begin{array}{c}\text { TB blood percentage } \\
\text { in stallions' pedigree }\end{array}$ \\
\hline Behavior score I & 0.068 \\
\hline Behavior score II & 0.033 \\
Behavior score III & 0.064 \\
Total time I & $0.133^{\times}$ \\
Total time II & 0.095 \\
Total time III & 0.068 \\
HR before testing & 0.076 \\
HR I & 0.006 \\
HR II & 0.088 \\
\hline HR III & 0.009 \\
\hline${ }^{x}$ significant at P $\leq 0.05$ & \\
\hline
\end{tabular}

Table 5. Correlation coefficients between performance tests scores in stallions and TB ancestor's blood percentage in stallions' pedigree

\begin{tabular}{|lc|}
\hline $\begin{array}{l}\text { Performance traits evaluated by } \\
\text { T- trainer, J- judges, R - test rider }\end{array}$ & $\begin{array}{c}\text { TB blood percentage } \\
\text { in stallions' pedigree }\end{array}$ \\
\hline Trainability $(\mathrm{T})$ & -0.092 \\
\hline Character $(\mathrm{T})$ & $-0.133^{\times}$ \\
\hline Temperament $(\mathrm{T})$ & -0.029 \\
\hline Free jumping $(\mathrm{T})$ & -0.011 \\
\hline Jumping under rider $(\mathrm{T})$ & -0.026 \\
\hline Walk $(\mathrm{T})$ & -0.040 \\
\hline Trot $(\mathrm{T})$ & $-0.144^{\times}$ \\
\hline Canter $(\mathrm{T})$ & -0.024 \\
\hline Free jumping $(\mathrm{J})$ & -0.045 \\
\hline Jumping under rider $(\mathrm{J})$ & 0.032 \\
\hline Walk $(\mathrm{J})$ & 0.003 \\
\hline Trot $(\mathrm{J})$ & -0.094 \\
\hline Canter $(\mathrm{J})$ & -0.005 \\
\hline Rideability $(\mathrm{R})$ & $-0.135^{\times}$ \\
\hline Rideability dressage $(\mathrm{R})$ & -0.093 \\
\hline Rideability jumping $(\mathrm{R})$ & -0.073 \\
\hline Final index $(\mathrm{J})$ & -0.022 \\
\hline${ }^{x}$ significant at $\mathrm{P} \leq 0.05$ & \\
\hline
\end{tabular}




\section{DISCUSSION}

This study on warmblood stallions showed some significant correlations between Thoroughbred ancestors blood percentage and the level of some fearfulness and performance test scores. Some authors [20-24] pointed out that genetic factors appeared to have a great impact on sport performance and behavior characteristics of horses, especially their neophobic responses. Research on genetic influence can include breed differences, sire impact or influence of proportions of founder ancestors in the individual's pedigree. For example, Černohorska et al [19] found that the performance of the offspring of Dutch warmblood, Hanoverian horse and Holsteiner horse sires was better than of the offspring of sires of Thoroughbred, Czech warmblood and Selle Francais breeds. The poorest conformation, as well as the mechanics of movement and the jumping ability, were identified in the offspring of Thoroughbred sires [19]. Several studies investigating temperament identified that the sire seemed to be the genetic factor effecting fear reactions of horses to new objects [20,22]. Additionally, a sire effect was found in the tendency to develop stereotypic behavior [25]. Only a few studies estimated the heritability of horses behavior responses in practical situations. Oki et al [26] found higher heritability (0.23-0.28) of behavior reactions to veterinarian inspection than the study by Rothmann et al [27] showing a low heritability (0.17) of equine reactivity observed during the evaluation of the horse conformation at field tests. Breed-related differences in fear behavior have been described by a number of authors [21,24,28]. Janiszewska et al. [28] also found in the fearfulness test (the same as used in the present study) conducted during the performance test for Polish sport stallions that horses of Holsteiner breed were less reactive than Thoroughbreds or Thoroughbred crosses. The studies on personality traits identified the Thoroughbreds as the most reactive of a sample of sixteen [21] or eight [24] horse breeds in the research exploring the association between breed and specific behavior. Hausberger et al. [21] found breed differences in the length of time taken to cross the 'bridge' test. Lloyd et al. [24] also noted that Thoroughbreds behaved significantly more excitably and anxiously than other breeds included in the study based on the Horse Personality Questionnaire. Our results show that the higher proportions of TB ancestors blood in the stallions pedigree were related with the higher values for total time to pass the novel objects when led by a handler during the fearfulness test. The present results are comparable to the findings of a previous study by König v. Borstel et al. [12] on temperament and performance testing in horses. Their study indicated that warmbloods with a high proportion of Thoroughbred were more reactive to different novel stimuli (visual, tactile and auditory stimuli) when evaluated by the rider as well as the judges than warmbloods with a low proportion of Thoroughbred in their pedigree.

Recent studies have shown that behavioral responses combined with physiological data are reliable measurements of equine reactivity [2,8,29-31]. For example, Momozawa et al [29] found that Thoroughbreds showed higher heart rate values and a higher frequency of fearful behavior when confronted with a novel object than Anglo- 
Arabians. We found not only significant positive correlations between the ancestors blood percentages and the total time values in the fearfulness test but it was also shown that the stallions with a higher proportion $(>75.00 \%)$ of TB blood revealed higher values of HR measured at the riding hall just before the start of the fearfulness test. These relationships can suggest that the stallions with a high proportion of TB blood were more reactive to the test stimuli in the fearfulness test than the stallions with a low proportion of these ancestors in their pedigree.

Novel-object based temperament tests can be conducted in free-running or led horses as well as under a rider $[8,12,17,18]$. In the present study on stallions fearfulness the horses were led by a handler. König v. Borstel et al. [12] noted that temperament tests involving human interactions are especially important since the human-horse relations are the most relevant aspects regarding their suitability as work-, sport- as well as leisure horses. Le Scolan et al. [32] identified that the time to pass a novel object when led by a handler was more related with owner's assessment of a horse's fearfulness during work compared to their behavior score in a novel object test without human interference. Horses tend to react with avoidance or flight to potentially frightening situations, however, with repeated exposure, they become accustomed to their surroundings and cease to avoid non-threatening stimuli. The present study showed decreased behavioral and heart rate reactivity in warmblood stallions (regardless their ancestors proportion) within the fearfulness test sessions II and III that could be a result of habituation to the test stimuli. This is comparable to the results of König v. Borstel et al. [12] who, using a novel-object based temperament test, found that horses with a high proportion of TB in their pedigree did not differ significantly from horses with a low proportion of TB regarding habituation to stimuli. These results could be due to the fact that the horses in both studies were warmblood crosses, rather than purebred Thoroughbreds and this view is shared by König v. Borstel et al. [12].

Several studies investigating the quality of performance traits have shown that they can be modified by various factors related to age, sex and genetic influences [2-4,33,34]. Olsson et al [33] found that traits tested in the stallion performance test had medium high to high heritability coefficients which imply that this test is an efficient tool for selecting breeding stallions. However, some authors underline that the assessment of equine personality traits (temperament and character) as a part of standardized performance test should involve not only subjective trainer's or judge's evaluation but also horse reactivity assessment based on objective behavior tests [2,12]. When horse breeding is primarily intended for using them by amateur riders as leisure horses, personality traits (character and temperament) may have a higher weighting than sport performance [1]. We found that a high proportion of TB blood negatively influenced the score for character. Rideability is a trait of common interest to different groups of riders [1] and the present study showed a significant negative correlation between the trait of rideability evaluated by the test rider and the TB ancestors blood percentage. The study on Czech sport horses identified that horses with no significant proportion of Thoroughbreds in the pedigree showed the highest level of performance in show 
jumping competitions [22]. A greater understanding of the need for genetic evaluation and more objective assessment of behavior-related traits may aid the selection of stallions for specific equine disciplines including use for sports and leisure.

\section{CONCLUSIONS}

Based on this study, it could be concluded that the amount of crossbreeding with Thoroughbreds, which are apparently present to some extent in the warmblood stallions pedigree, may be one of the important factors for riding horses traits related to their fearfulness and performance. The findings imply that a high proportion of Thoroughbreds in the pedigree may negatively influence some performance traits and increase fear reactivity in warmblood stallions. Negative correlations were found between the TB percentage and the scores for character and trot evaluated by the trainer as well as rideability evaluated by the test rider in the performance tests. An increased proportion $(>75.00 \%)$ of TB blood in the stallions pedigree significantly influenced their heart rate measured at the riding hall before novel-object testing. The results showed that the higher proportions of TB ancestors blood in the stallions pedigree were correlated with the higher values for total time to pass the novel objects when led by a handler during the fearfulness test. The precise analysis of genetic relationships should be involved in the process of stallions selection for breeding, sport and leisure riding objectives together with temperament and performance assessment. The further research is needed to assess the impact of these genetic factors on the other personality components and stress reactivity in warmblood stallions.

\section{Authors' contributions}

$\mathrm{BM}$ and $\mathrm{KJ}$ participated in design and coordination of the study, performed interpretation of data, involved in drafting the manuscript and revising it critically for important intellectual content. MB performed interpretation of data, helped to draft the manuscript. SL participated in the design of the study and performed the statistical analysis. All authors read and approved the final manuscript.

\section{Declaration of conflicting interests}

The author(s) declared no potential conflicts of interest with respect to the research, authorship, and/or publication of this article.

\section{REFERENCES}

1. Koenen EPC, Algridge LI, Philipsson J: An overview of breeding objectives for warmblood sport horses. Livest Prod Sci 2004, 88:77-84.

2. Budzyńska M, Kamieniak J, Krupa W, Sołtys L: Behavioral and physiological reactivity of mares and stallions evaluated in performance tests. Acta Vet (Beograd) 2014, 64(3):327-337. 
3. Thorén Hellsten E, Viklund A, Koenen EPC, Ricard A, Bruns E, Philipsson J: Review of genetic parameters estimated at stallion and young horse performance tests and their correlations with later results in dressage and show-jumping competition. Livest Sci 2006, 103:1-12.

4. Wallin L, Strandberg E, Philipsson J: Genetic correlations between field tests results of Swedish Warmblood Horses as 4-years-olds and lifetime performance results in dressage and show jumping. Livest Prod Sci 2003, 82:61-71.

5. Graf P, König von Borstel U, Gauly M: Practical considerations regarding the implementation of a temperament test into horse performance tests: Results of a large-scale test run. J Vet Behav 2014, 9:329-340.

6. Visser EK, Karlas K, van Deurzen I, Workel I, van Reenen K: Experts' assessment of temperament in sport horses. J Vet Behav 2010, 5:214-215.

7. Graf P, König von Borstel U, Gauly M: Importance of personality traits in horses to breeders and riders. J Vet Behav 2013, 8:316-325.

8. Christensen JW, Rundgren M, Olsson K: Training methods for horses: habituation to a frightening stimulus. Equine Vet J 2006, 38:439-443.

9. Peeters M, Verwilghen D, Serteyn D, Vandenheede M: Relationships between young stallions' temperament and their behavioral reactions during standardized veterinary examinations. J Vet Behav 2012, 7:311-321.

10. Forkman B, Boissy A, Meunier-Salaün MC, Canali E, Jones RB: A critical review of fear tests used on cattle, pigs, sheep, poultry and horses. Physiol Behav 2007, 91: 531-565.

11. Budzyńska M: Stress reactivity and coping in horse adaptation to environment. J Equine Vet Sci 2014, 34(8):935-941.

12. König v. Borstel U, Pirsich W, Gauly M, Bruns E: Repeatability and reliability of scores from ridden temperament tests conducted during performance tests. Appl Anim Behav Sci 2012, 139:251-263.

13. Cervantes I, Gutiérrez JP, Molina A, Goyache F, Valera M: Genealogical analyses in open populations: the case of three Arab derived Spanish horse breeds. J Anim Breed Genet 2009, 126:335-347.

14. Thorén Hellsten E, Näsholm A, Jorjani H, Strandber E, Philipsson J: Influence of foreign stallions on the Swedish Warmblood breed and its genetic evaluation. Livest Sci 2009,121:207-214.

15. Bartolomé E, Cervantes I, Valera M, Gutiérrez JP: Influence of foreign breeds on the genetic structure of the Spanish Sport Horse population. Livest Sci 2011, 142:70-79.

16. Schröder W, Stock KF, Distl O: Genetic evaluation of Hanoverian warmblood horses for conformation traits considering the proportion of genes of foreign breeds. Arch Tierz 2010, 53(4):377-387.

17. Budzyński M: Fearfulness test used for assessment of nervous balance in horses. Med Weter 1984, 3:156-158.

18. Budzyńska M: Behavioural and physiological mechanisms of reactions to stressful stimuli in Arab horses. Lublin, Poland: DSc Dissertation no. 361, University of Life Sciences in Lublin Publishing; 2012.

19. Breeding Programs for Warmblood Horses by the Polish Horse Breeders Association (PHBA). [http://www.pzhk.pl].

20. Černohorska H, Sobotková E, Kostuková M, Bihuncová I, Oravcová I: Analysis of lines and breeds of sires in the breeding of the Czech warmblood horses based on grading their 
offspring in rearing facilities for testing young horses (RFT). Acta Univ Agric et Silvic Mendel Brun 2013, LXI(6):1605-1612.

21. Hausberger M, Bruderer C, Le Scolan N, Pierre JS: Interplay between environmental and genetic factors in temperament/personality traits in horses (Equus caballus). J Comp Psychol 2004, 118:434-446.

22. Jiskrová I: The effect of the English Thoroughbred on the sport performance of horses in the Czech Republic. Acta Univ Agric et Silvic Mendel Brun 2011, LIX(6):175-180.

23. Sapuła M, Kamieniak J, Sołtys L, Budzyńska M, Mazurek E, Budzyński M: Changes in behavioral indices of half-bred stallions from particular sire lines during training (100-days' test). Ann UMCS sec EE 2006, XXIV:185-190.

24. Lloyd AS, Martin JE, Bornett-Gauci HLI, Wilkinson RG: Horse personality: Variation between breeds. Appl Anim Behav Sci 2008, 112:369-383.

25. Vecchiotti G, Galanti R: Evidence of heredity of cribbing, weaving and stall walking in thoroughbred horses. Livest Prod Sci 1986, 14:91-95.

26. Oki H, Kusunose R, Nakaoka A, Miyake T, Sasaki Y: Estimations of heritability and genetic correlation for behavioural responses by Gibbs sampling in Thoroughbred racehorse. J Anim Breed Genet 2007, 124:185-191.

27. Rothmann J, Christensen OF, Søndergaard E, Ladewig J: A note on the heritability of reactivity assessed at Field Tests for Danish Warmblood Horses. J Equine Vet Sci 2014, 34:341-343.

28. Janiszewska J, Ignor J, Cieśla A: Modifying influence of 11-months training on results of ‘timidity' test of young halfbred stallions. Arch Tier 2004, 1:7-13.

29. Momozawa Y, Ono T, Sato F, Kikusui T, Takeuchi Y, Mori Y, Kusunose R: Assessment of equine temperament by a questionnaire survey to caretakers and evaluation of its reliability by simultaneous behavior test. Appl Anim Behav Sci 2003, 84:127-138.

30. Christensen JW, Keeling LJ, Nielsen BL: Responses of horses to novel visual, olfactory and auditory stimuli. Appl Anim Behav Sci 2005, 93:53-65.

31. McCall CA, Hall S, McElhenney WH, Cummins KA: Evaluation and comparison of four methods of ranking horses based on reactivity. Appl Anim Behav Sci 2006, 96:115-127.

32. Le Scolan N, Hausberger M, Wolff A: Stability over situations in temperamental traits of horses as revealed by experimental and scoring approaches. Behav Proc 1997, 41:257-266.

33. Olsson EG, Arnason T, Näsholm A, Philipsson J: Genetic parameters for traits at performance test of stallions and correlations with traits at progeny tests in Swedish warmblood horses. Livest Prod Sci 2000, 65:81-89.

34. Lewczuk D: Effect of the age on performance tests in Warmblood horses in Poland. J Vet Behav 2014, 10:413-418. 


\title{
POVEZANOST ZASTUPLJENOSTI ČISTOKRVNIH KONJA U PEDIGREU SA STEPENOM PLAŠLJIVOSTI I PERFORMANSAMA TOPLOKRVNIH PASTUVA
}

\author{
BUDZYŃSKA Monika, KAMIENIAK Jarosław, MARCINIAK Beata, \\ SOLTYS Leszek
}

Cilj studije je bio da se testira hipoteza da procenat čistokrvnih predaka u pedigreu predstavlja potencijalni faktor u razlikovanju nivoa straha (zasnovano na ponašanju i srčanom pulsu) kao i u skorovima performansi kod toplokrvnih pastuva. Ukupno je ispitano 267 toplokrvnih pastuva, starosti tri godine. Tokom učešća u test programu određivanja performansi primenjen je test u okviru koga su ispitivane reakcije na nove objekte u manježu. Zastupljenost učešća predaka u pedigreu je analizirana tako što su konji podeljeni u četiri grupe u odnosu na procentualni udeo predaka u naslednom materijalu: prva grupa $<25,01 \%$, druga grupa 25,01-50,00\%, treća grupa 50,01-75,00\% i četvrta grupa $>75,00 \%$. Uočeno je da je kod pastuva sa većim procentom učešća čistokrvnih predaka (preko 75,00\%) puls bio povećan u manježu, neposredno pre početka obavljanja testa plašljivosti. Rezultati ukazuju da se veća proporcija čistokrvnih predaka u okviru pedigrea pastuva nalazi u korelaciji sa većim vrednostima ukupnog vremena za prolazak kroz nove objekte u manježu, kada su vođeni sa konjovodcem, a tokom testa ispitivanja plašljivosti. Uočena je negativna korelacija između procenta čistokrvnih predaka i skorova karaktera i kasa pri čemu je evaluaciju obavljao trener. Ista korelacija je uočena i u slučaju lakoće jahanja, pri čemu je evaluaciju ove karakteristike obavljao test džokej. Ovi rezultati ukazuju da veći udeo nasledne osnove čistokrvnih predaka u pedigreu, može negativno uticati na neke karakteristike performansi i stepen plašljivosti kod toplokrvnih pastuva. 